\title{
Chiral terpene auxiliaries V: Synthesis of new chiral $\gamma$-hydroxyphosphine oxides derived from $\alpha$-pinene
}

\author{
Anna Kmieciak and Marek P. Krzemiński
}

\author{
Full Research Paper \\ Address: \\ Faculty of Chemistry, Nicolaus Copernicus University in Toruń, 7 \\ Gagarin St., 87-100 Toruń, Poland \\ Email: \\ Marek P. Krzemiński* - mkrzem@chem.umk.pl \\ * Corresponding author \\ Keywords: \\ isopinocamphone; monoterpenes; phosphines; [2,3]-sigmatropic \\ rearrangement; verbanone
}

\author{
Open Access \\ Beilstein J. Org. Chem. 2019, 15, 2493-2499. \\ doi:10.3762/bjoc. 15.242 \\ Received: 08 May 2019 \\ Accepted: 09 October 2019 \\ Published: 22 October 2019 \\ This article is dedicated to Professor Marek Zaidlewicz on the occasion of \\ his 80th birthday. \\ Associate Editor: S. Bräse \\ (C) 2019 Kmieciak and Krzemiński; licensee Beilstein-Institut. \\ License and terms: see end of document.
}

\begin{abstract}
New chiral regioisomeric $\gamma$-hydroxyphosphine ligands were synthesized from $\alpha$-pinene. The key transformation was the thermal [2,3]-sigmatropic rearrangement of allyldiphenylphosphinites, obtained from $(1 R, 2 R, 4 S, 5 R)$-3-methyleneneoisoverbanol and $(1 R, 2 R, 3 R, 5 R)$-4-methyleneneoisopinocampheol, to allylphosphine oxides. Hydroxy groups were introduced stereoselectively through a hydroboration-oxidation reaction proceeding from the less hindered site providing a trans relationship between the hydroxy and the phosphine substituents.
\end{abstract}

\section{Introduction}

Chiral phosphorus compounds, despite many years of research, still enjoy unflagging interest of many research groups [1]. Compounds with a phosphorus atom attached to a stereogenic carbon center in acyclic and cyclic structures play an important role as chiral ligands in transition metal complexes [2]. They were applied to various catalytic asymmetric reactions $[3,4]$, such as hydrogenations [3-6], conjugated additions to enones [7], and allylic alkylations [8,9]. Another direction of research is the use of phosphines in organocatalysis $[10,11]$ and bifunctional catalysis [12].

Several methods were developed to introduce the phosphine functionality to organic molecules. The reaction of organometallics with chlorophosphines, the reaction of metal phosphides with haloalkanes, and transition-metal-catalyzed cross-coupling reactions to form $\mathrm{C}-\mathrm{P}$ bonds are the most widely used methods for the synthesis of phosphines [13,14]. Since phosphines are easily oxidized to phosphine oxides, the addition of phosphine oxide $\mathrm{P}-\mathrm{H}$ nucleophiles were also realized [15]. The phosphine oxide group can also be introduced starting from allylic alcohols employing the rearrangement of allylic diphenylphosphinites to allylphosphine oxides [16,17].

Recently, we have shown the synthesis and applications of chiral PHOX ligands that were obtained from readily available natural (1S)- $\beta$-pinene and (1S)- $\alpha$-pinene [18]. We applied these 
ligands for the formation of the ruthenium complexes, which were successfully used as catalysts in asymmetric transfer hydrogenation of prochiral ketones.

In continuation of our studies on the synthesis of monoterpene derived ligands, we have utilized commercially available $(1 R)$ $\alpha$-pinene and ( $1 S)$ - $\beta$-pinene to obtain regioisomeric exocyclic and endocyclic allylic alcohols, which were applied for the synthesis of $\gamma$-hydroxydiphenylphosphine ligands. To the best of our knowledge, only Knochel and co-workers synthesized diphosphines with a pinane framework [19].

\section{Results and Discussion Synthesis of allylic alcohols}

In the first step, commercially available natural $(1 R)$ - $\alpha$-pinene (1) was oxidized with lead(IV) acetate to produce (+)verbenone (2) in 58\% yield (Scheme 1) [20]. Hydrogenation of 2 with Adams catalyst was carried out in cyclohexane with 1 atm of hydrogen. The hydrogen pressure was increased to $10 \mathrm{~atm}$ for the reaction performed in an autoclave on a larger scale maintaining the high selectivity of hydrogen addition from the less hindered side of the molecule. $(1 R, 2 S, 5 R)-(+)-$ Verbanone (3) was obtained in $93 \%$ yield. GC analysis of 3 showed the presence of cis and trans diastereoisomers in a ratio of 97:3. The hydrogen-addition selectivity is consistent with earlier literature reports and results from the shielding effect of the gem-dimethyl bridge [21,22].

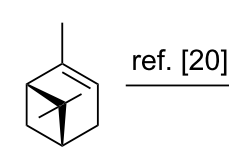

1

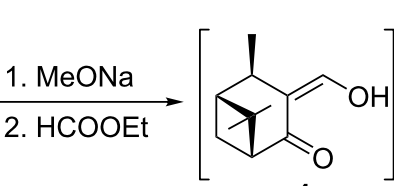

4

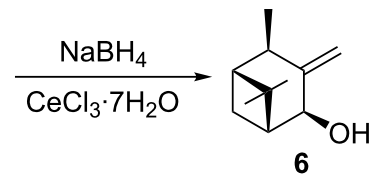

Scheme 1: Synthesis of $(1 R, 2 R, 4 S, 5 R)$-3-methyleneneoisoverbano (6).

In the next step, $\mathbf{3}$ reacted with sodium methoxide in toluene and the resulting enolate was condensed with ethyl formate to give a keto-aldehyde, which tautomerized into the more stable $\beta$-hydroxyenone 4 [23]. The intermediate 4 was sufficiently pure for the subsequent transaldolization reaction with form- aldehyde in the presence of sodium carbonate to give (+)-3methyleneverbanone (5) in 57\% yield from 3. $\alpha, \beta$-Unsaturated ketone 5 was exclusively reduced to allylic alcohol $(1 R, 2 R, 4 S, 5 R)$-3-methyleneneoisoverbanol (6), using the Luche method [24]. 1,2-Reduction of enone 5 was achieved with sodium borohydride in the presence of cerium(III) chloride in methanol in $88 \%$ yield (Scheme 1).

The synthesis of allylic alcohol 11, a regioisomer of $\mathbf{6}$, started again from (1R)- $\alpha$-pinene (1, Scheme 2). Hydroboration of $(1 R)$ - $\alpha$-pinene with borane-dimethyl sulfide adduct (BMS) and crystallization of the product diisopinocampheylborane $\left({ }^{d} \mathrm{Ipc}_{2} \mathrm{BH}, 84 \%\right.$ yield) allowed to upgrade the enantiomeric purity of ${ }^{d} \mathrm{Ipc}_{2} \mathrm{BH}$ [25]. Oxidation of the resulting dialkylborane with hydrogen peroxide provided enantiomerically pure (-)-isopinocampheol (7) in 78\% yield. The Brown-Garg protocol [26] was employed to oxidize 7 with an aqueous solution of sodium dichromate and sulfuric acid under biphasic conditions. (-)-Isopinocamphone $(\mathbf{8})$ was purified by fractional distillation and isolated in $78 \%$ yield. Then, 8 was subjected to an analogous reaction sequence that was used for (+)-verbanone (3), i.e., the synthesis of the enone in the first step followed by its 1,2-reduction to the allylic alcohol. Thus, Claisen condensation of $\mathbf{8}$ with ethyl formate gave $\beta$-hydroxyenone $\mathbf{9}$, which was subjected to transaldolization with formaldehyde producing the corresponding 4-methyleneisopinocamphone (10) in $83 \%$ yield. Luche reduction of the latter compound provided $(1 R, 2 R, 3 R, 5 R)$-4-methyleneneoisopinocampheol (11) in $84 \%$ yield.
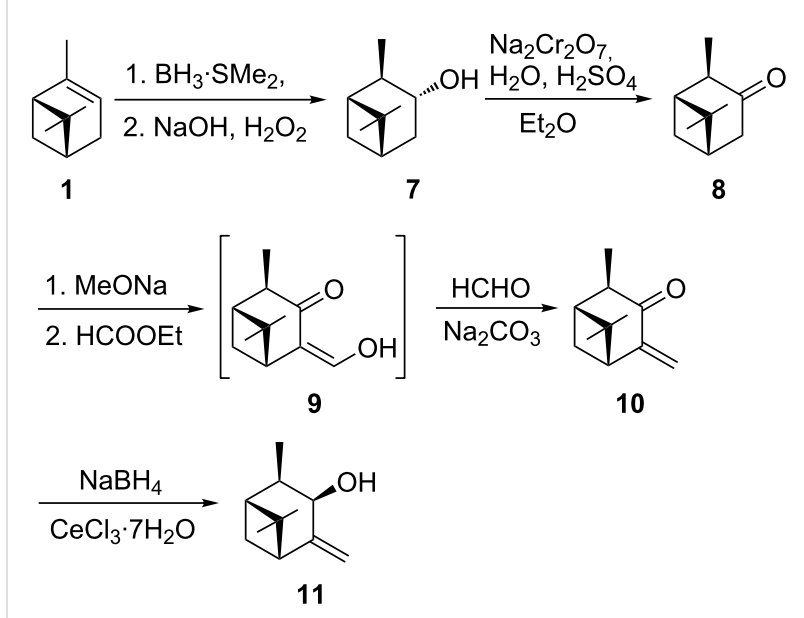

Scheme 2: Synthesis of $(1 R, 2 R, 3 R, 5 R)-4$-methyleneneoisopinocampheol (11).

In order to obtain two endocyclic allylic alcohols, (-)- $\beta$-pinene was chosen as the starting material for this synthesis (Scheme 3). Thus, $\beta$-pinene (12) was reacted with ozone to give 
(+)-nopinone (13) in $90 \%$ yield [27]. In the next step, $\mathbf{1 3}$ reacted with diphenyl diselenide and selenium dioxide in methanol [28]. The obtained phenyl selenide $\mathbf{1 4}$ was oxidized with hydrogen peroxide in the presence of pyridine to selenoxide, which readily undergoes intramolecular syn-elimination to produce $\alpha, \beta$-unsaturated (+)-apoverbenone (15) [28,29]. In the next step, Luche reduction of $\mathbf{1 5}$, proceeding from the less hindered side of the carbonyl group, gave $(1 R, 4 R, 5 R)$-apopinenol (16) in $95 \%$ yield. GC analysis of $\mathbf{1 6}$ has shown the presence of the expected major isomer $(1 R, 4 R, 5 R)-\mathbf{1 6}(92 \%)$ and the minor isomer $(1 R, 4 S, 5 R)-\mathbf{1 8}(8 \%)$. Diastereomers $\mathbf{1 6}$ and $\mathbf{1 8}$ can be separated by flash column chromatography on silica gel. For the purpose of this study, $(1 R, 4 R, 5 R)$-apopinenol (16) was subjected to the Mitsunobu reaction to obtain the product with inverted configuration at $\mathrm{C} 4$. Alcohol 16 was reacted with diisopropyl azodicarboxylate, triphenylphosphine, and $p$-nitrobenzoic acid in THF [30]. ${ }^{1} \mathrm{H}$ NMR analysis of the crude $p$-nitrobenzoate $\mathbf{1 7}$ revealed a mixture of the predicted $p$-nitrobenzoate of apopinenol $\mathbf{1 8}$ together with an ester of $\mathbf{1 6}$ in a ratio of 79:21. Attempts to separate $p$-nitrobenzoates of $\mathbf{1 8}$ and $\mathbf{1 6}$ by column chromatography on silica gel failed. The mixture of esters, after purification, was hydrolyzed with a $5 \%$ aqueous solution of $\mathrm{NaOH}$. GC analysis of the isolated alcohol confirmed the presence of $(1 R, 4 S, 5 R)$-apopinenol $(\mathbf{1 8})$ and $(1 R, 4 R, 5 R)-\mathbf{1 6}$ in a ratio of 79.5:20.5.

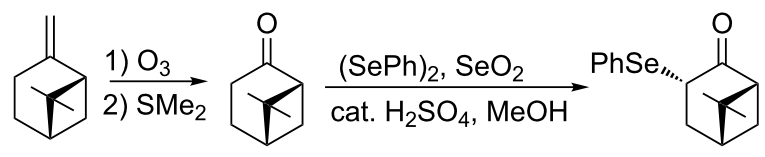

12

13

14
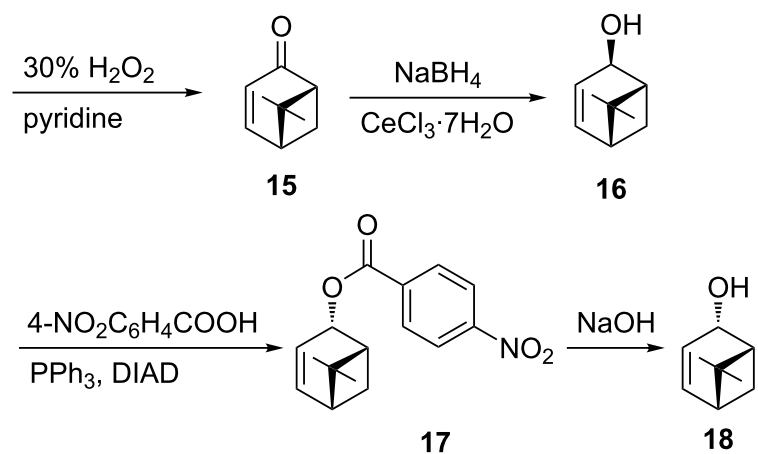

Scheme 3: Synthesis of allylic alcohols 16 and 18 from $\beta$-pinene.

The structures and stereochemistry of both diastereomeric alcohols 16 and 18 were confirmed by 2D NMR spectra. All protons in 16 and 18 were assigned using ${ }^{1} \mathrm{H},{ }^{1} \mathrm{H}-\mathrm{COSY}$ spectra. The configurations at $\mathrm{C} 4$ were established by correlations observed in their ${ }^{1} \mathrm{H},{ }^{1} \mathrm{H}-\mathrm{NOESY}$ spectra (Figure 1, Supporting Information File 1).

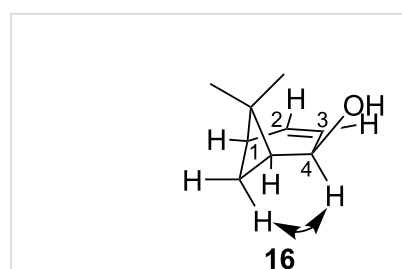

Figure 1: NOE effects in molecules $\mathbf{1 6}$ and $\mathbf{1 8}$

\section{Synthesis of $Y$-hydroxyphosphines}

The key step in the synthesis to introduce a phosphine functionality is the thermal [2,3]-sigmatropic rearrangement of an allylic diphenylphosphinite to the diphenylphosphine oxide (Scheme 4) [16].

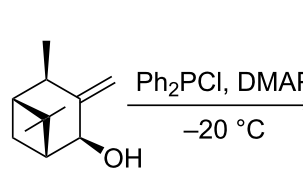

6

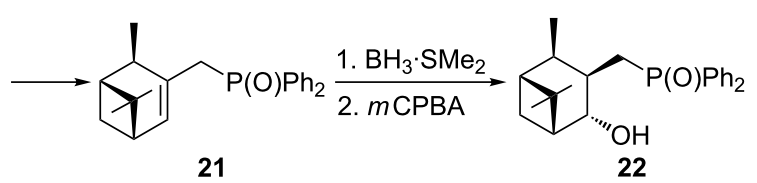

21

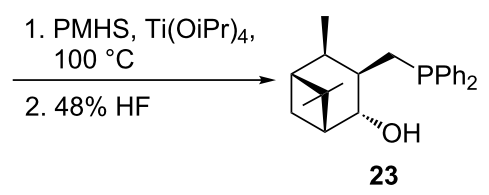

Scheme 4: Synthesis of $(1 R, 2 R, 3 R, 4 R, 5 R)-3-(($ diphenylphosphanyl)methyl)isoverbanol (23).

Diphenylphosphinite 19 was formed in the reaction of allylic alcohol 6 with diphenylphosphine chloride in the presence of DMAP at $-20{ }^{\circ} \mathrm{C}$. The temperature was raised to induce phosphinite's [2,3]-sigmatropic rearrangement (20) as shown in Scheme 4. The reaction progress, conversion of $\mathbf{1 9}$ into 21, was monitored by ${ }^{31} \mathrm{P}$ NMR $\left(\mathrm{ROPPh}_{2} \delta=113 \mathrm{ppm}\right.$; $\mathrm{RP}(\mathrm{O}) \mathrm{Ph}_{2}$ $\delta=30 \mathrm{ppm})$. The phosphinite 19 disappeared after $48 \mathrm{~h}$ at $100{ }^{\circ} \mathrm{C}$. The product was crystallized from heptane to give phosphine oxide 21 in $92 \%$ yield. The allylic diphenylphosphine oxide 21 was subjected to the hydroboration-oxidation reaction introducing stereoselectively the hydroxy group. Hydroboration was carried out with an excess of borane-dimethyl sulfide adduct followed by the oxidation step. The standard $\mathrm{C}-\mathrm{B}$ bond oxidation protocol $\left(\mathrm{H}_{2} \mathrm{O}_{2} / \mathrm{NaOH}\right)$ proceeded with the low yield (32\%). Application of $m$-chloroperbenzoic acid $(m \mathrm{CPBA})$ as an oxidant, similarly to 
Knochels findings [19], gave the higher yield (56\%) of (((1R,2R,3R,4R,5R)-4-hydroxypinan-3-yl)methyl)diphenylphosphine oxide (22).

Next, phosphine oxide 22 was reduced to the phosphine with poly(methylhydrosiloxane) in the presence of titanium(IV) isopropoxide (Scheme 4). The work-up of the reaction mixture with $25 \% \mathrm{HF}$ allowed to remove silicon and titanium impurities and purification of $\mathbf{2 3}$ by column chromatography on silica gel yielded the product in $62 \%$.

4-Methyleneneoisopinocampheol (11) was subjected to the same reaction sequence as $\mathbf{6}$ (Scheme 5). The allylphosphine oxide 26 was obtained after [2,3]-sigmatropic rearrangement of phosphinite 24. After purification by column chromatography on silica gel, 26 was obtained in 78\% yield. The hydroboration of 26 was carried out with borane-dimethyl sulfide adduct in THF at $50{ }^{\circ} \mathrm{C}$. Oxidation of the alkylborane with $m$ CPBA gave the desired alcohol 27 in $51 \%$ overall yield.

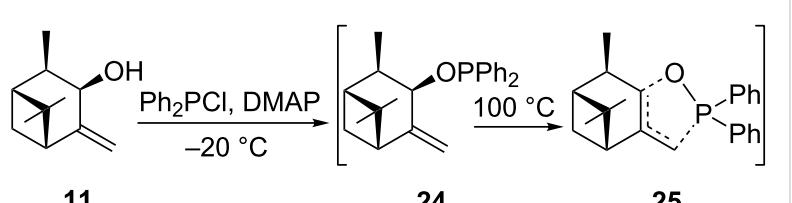
11 24 25

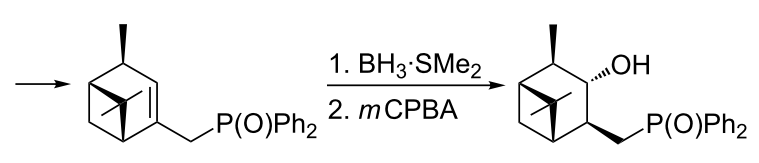

26

27

Scheme 5: Synthesis of $(((1 R, 2 R, 3 S, 4 S, 5 S)$-3-hydroxypinan-4$\mathrm{yl}$ )methyl)diphenylphosphine oxide (27).

Finally, diastereomeric endocyclic allylic alcohols $\mathbf{1 6}$ and $\mathbf{1 8}$ were treated with chlorodiphenylphosphine in the presence of DMAP to produce diphenylphosphinites 28 and $29\left({ }^{31} \mathrm{P}\right.$ NMR: $\mathrm{ROPPh}_{2} \delta=107 \mathrm{ppm}$ ), respectively (Scheme 6). Attempts to carry out a sigmatropic rearrangement in toluene at $100{ }^{\circ} \mathrm{C}$ as well as in xylene at $140{ }^{\circ} \mathrm{C}$ failed. The formation of the phosphine oxide products was not observed by ${ }^{31} \mathrm{P}$ NMR analysis. The probable reason for the lack of the rearrangement reaction may be the rigid bicyclic structure of the substrate and steric hindrance on one side of the molecule caused by the gemdimethyl bridge.

\section{Conclusion}

Regioisomeric exocyclic allylic alcohols were synthesized from natural $\alpha$-pinene. $(1 R, 2 R, 4 S, 5 R)$-3-Methyleneneoisoverbanol and $(1 R, 2 R, 3 R, 5 R)$-4-methyleneneoisopinocampheol were synthesized using known procedures. They were used in the key

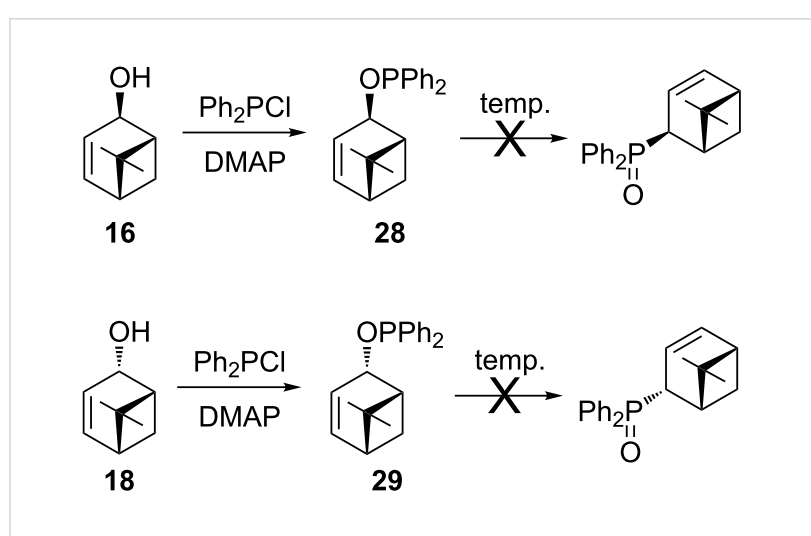

Scheme 6: Attempted sigmatropic rearrangement of phosphinites 28 and 29.

transformation, the thermal [2,3]-sigmatropic rearrangement of allyldiphenylphosphinites to allyldiphenylphosphine oxides. Allylphosphine oxides were further functionalized through a hydroboration-oxidation reaction occurring from the less hindered side of the molecule to produce $\gamma$-hydroxyphosphine oxide derivatives. It was also shown that phosphine oxide can be reduced to phosphine without affecting the bicyclic pinane structure.

The synthesis of diastereomeric endocyclic allylic alcohols from (-)- $\beta$-pinene was also carried out. Unfortunately, due to the probably too rigid bicyclic structure of the diphenylphosphinites, they did not undergo the sigmatropic rearrangement to the corresponding phosphine oxides. Further research and application of the obtained ligands are in progress.

\section{Experimental Diphenyl (((1R,2R,5S)-ס-pinen-3- yl)methyl)phosphine oxide (21)}

Allylic alcohol $6(0.831 \mathrm{~g}, 5 \mathrm{mmol})$ and 4-dimethylaminopyridine $(0.645 \mathrm{~g}, 5.3 \mathrm{mmol})$ were placed in a Schlenk flask. These compounds were dissolved in toluene $(10 \mathrm{~mL})$ under nitrogen. The solution was cooled below $-20{ }^{\circ} \mathrm{C}$ and diphenylphosphine chloride (1.106 g, $5 \mathrm{mmol}$ ) was added dropwise. After the removal of the cooling bath, the solution was stirred for $24 \mathrm{~h}$ at $100{ }^{\circ} \mathrm{C}$. After this time, the ${ }^{31} \mathrm{P}$ NMR spectrum has shown incomplete conversion of the substrate. Consequently, heating was continued until the ${ }^{31} \mathrm{P}$ NMR spectrum showed complete substrate conversion $(48 \mathrm{~h})$. Warm toluene $(10 \mathrm{~mL})$ was added to the reaction mixture and the solution was filtered through a pad of celite. The precipitate was washed with another portion of warm toluene $(10 \mathrm{~mL})$. The solvent was removed using a rotary evaporator to give the phosphine oxide. After crystallization from heptane, phosphine oxide 21 (1.612 g, $92 \%$ ) was obtained as a white solid, mp $127-131{ }^{\circ} \mathrm{C},[\alpha]_{\mathrm{D}}^{25}-98$ (c 2.4, $\left.\mathrm{CHCl}_{3}\right) ;{ }^{1} \mathrm{H}$ NMR (700 MHz, $\left.\mathrm{CDCl}_{3}\right) \delta 0.87(\mathrm{~d}, J=$ 
$8.5 \mathrm{~Hz}, 1 \mathrm{H}), 0.89$ (s, 3H, $\left.\mathrm{CH}_{3}\right), 1.14$ (d, $J=7.5 \mathrm{~Hz}, 3 \mathrm{H}, \mathrm{CH}_{3}$ ), $1.20\left(\mathrm{~s}, 3 \mathrm{H}, \mathrm{CH}_{3}\right), 1.95-1.96(\mathrm{~m}, 2 \mathrm{H}), 2.23(\mathrm{dt}, J=8.4,5.6 \mathrm{~Hz}$, $1 \mathrm{H}), 2.56(\mathrm{~s}, 1 \mathrm{H}), 3.08-3.12(\mathrm{~m}, 1 \mathrm{H}), 3.20-3.25(\mathrm{~m}, 1 \mathrm{H}), 5.97$ (s, 1H), 7.45-7.48 (m, 4H), 7.49-7.53 (m, 2H), 7.76-7.80 (m, $4 \mathrm{H}) ;{ }^{13} \mathrm{C} \mathrm{NMR}\left(100 \mathrm{MHz}, \mathrm{CDCl}_{3}\right) \delta 16.78(\mathrm{~d}, J=1.6 \mathrm{~Hz})$, 23.73, 27.11, 33.52, $34.29(\mathrm{~d}, J=4.0 \mathrm{~Hz}), 38.22(\mathrm{~d}, J=4 \mathrm{~Hz})$, $42.30(\mathrm{~d}, J=5.6 \mathrm{~Hz}), 42.31,48.33,128.33(\mathrm{~d}, J=11.9 \mathrm{~Hz})$, $128.51(\mathrm{~d}, J=11.9 \mathrm{~Hz}), 129.09,129.19,130.84(\mathrm{~d}, J=9.5 \mathrm{~Hz})$, $131.23(\mathrm{~d}, J=8.7 \mathrm{~Hz}), 131.60(\mathrm{~d}, J=8.7 \mathrm{~Hz}), 131.64(\mathrm{~d}, J=$ $9.0 \mathrm{~Hz}), 135.87(\mathrm{~d}, J=8.0 \mathrm{~Hz}), 135.90(\mathrm{~d}, J=9.5 \mathrm{~Hz})$; ${ }^{31} \mathrm{P}$ NMR $\left(162 \mathrm{MHz}, \mathrm{CDCl}_{3}\right) \delta 31.76$; anal. calcd for $\mathrm{C}_{23} \mathrm{H}_{27} \mathrm{OP}$ : C, 78.83; H, 7.77; found: C, 78.73; H, 7.61.

\section{(((1R,2R,3R,4R,5R)-4-Hydroxypinan-3- yl)methyl)diphenylphosphine oxide (22)}

Phosphine oxide 21 (1.402 g, $4 \mathrm{mmol}$ ) was dissolved in THF $(13 \mathrm{~mL})$ under nitrogen. BMS (10 M, $0.8 \mathrm{~mL}, 8 \mathrm{mmol})$ was added dropwise to the reaction mixture. The mixture was stirred for $24 \mathrm{~h}$ at $50{ }^{\circ} \mathrm{C}$. After this time, the solution was cooled to room temperature and methanol $(6 \mathrm{~mL})$ was carefully added until the gas evolution ceased. Solvents were removed using a rotary evaporator and the resulting intermediate was dissolved in dichloromethane $(6 \mathrm{~mL})$. meta-Chloroperbenzoic acid $(75 \%$, $2.301 \mathrm{~g}, 10 \mathrm{mmol}$ ) was dissolved in dichloromethane $(10 \mathrm{~mL})$, cooled in a dry ice-acetone bath, and the intermediate solution was added dropwise. After $3 \mathrm{~h}$, the mixture was filtered, 10\% sodium metabisulphite $(15 \mathrm{~mL})$ was added to the filtrate, and the mixture was stirred for $10 \mathrm{~min}$. The layers were separated, the organic layer was washed with $1 \mathrm{M} \mathrm{NaOH}(2 \times 15 \mathrm{~mL})$, brine $(10 \mathrm{~mL})$, and dried over anhydrous magnesium sulfate. The solution was filtered, the solvent evaporated on a rotary evaporator and the product was purified by flash chromatography on silica gel (dichloromethane/diethyl ether 10:90). Phosphine oxide $22(0.825 \mathrm{~g}, 56 \%)$ was obtained as an oil.

In a second oxidation procedure, methanol $(5 \mathrm{~mL})$ and a $3 \mathrm{M}$ solution of sodium hydroxide $(2.7 \mathrm{~mL}, 8.1 \mathrm{mmol})$ were carefully added. After cooling to $0{ }^{\circ} \mathrm{C}$, a $30 \%$ solution of hydrogen peroxide $(1.2 \mathrm{~mL}, 12 \mathrm{mmol})$ was added dropwise to the reaction mixture. The solution was stirred for 30 minutes at $\mathrm{rt}$ and $1 \mathrm{~h}$ at $50{ }^{\circ} \mathrm{C}$. After this time, potassium carbonate was added to saturate the solution. The layers were separated and the aqueous layer was extracted with diethyl ether $(2 \times 20 \mathrm{~mL})$. The combined organic layers were washed with brine $(15 \mathrm{~mL})$, dried with anhydrous magnesium sulfate, filtered and the solvents were removed using a rotary evaporator. The product was purified by column chromatography on silica gel (dichloromethane/ diethyl ether 10:90). 22 (0.472 g, 32\%) was isolated as a white solid (mp 179-183 $\left.{ }^{\circ} \mathrm{C},[\alpha]_{\mathrm{D}}^{23}-39(c) 3.0, \mathrm{CHCl}_{3}\right) ;{ }^{1} \mathrm{H} \mathrm{NMR}$ $\left(400 \mathrm{MHz}, \mathrm{CDCl}_{3}\right) \delta 0.91\left(\mathrm{~s}, 3 \mathrm{H}, \mathrm{CH}_{3}\right), 1.05(\mathrm{~d}, J=7.3 \mathrm{~Hz}, 3 \mathrm{H}$, $\left.\mathrm{CH}_{3}\right), 1.22\left(\mathrm{~s}, 3 \mathrm{H}, \mathrm{CH}_{3}\right), 1.38(\mathrm{~d}, J=9.3 \mathrm{~Hz}, 1 \mathrm{H}), 1.87-1.93$ (m, 1H), 2.05-2.13 (m, 2H), 2.30-2.46 (m, 3H), 2.54-2.61 (m, $1 \mathrm{H}), 4.02(\mathrm{~d}, J=4.2 \mathrm{~Hz}, 1 \mathrm{H}), 7.46-7.58(\mathrm{~m}, 6 \mathrm{H}), 7.74-7.82(\mathrm{~m}$, $4 \mathrm{H}) ;{ }^{13} \mathrm{C} \mathrm{NMR}\left(100 \mathrm{MHz}, \mathrm{CDCl}_{3}\right) \delta 16.84,23.18,25.39,27.79$, $32.13(\mathrm{~d}, J=69.1 \mathrm{~Hz}), 36.32(\mathrm{~d}, J=12.7 \mathrm{~Hz}), 37.52(\mathrm{~d}, J=$ $4.0 \mathrm{~Hz}), 39.48,47.36,48.80,75.87,128.74(\mathrm{~d}, J=9.5 \mathrm{~Hz})$, $128.86(\mathrm{~d}, J=10.3 \mathrm{~Hz}), 130.45(\mathrm{~d}, J=9.5 \mathrm{~Hz}), 131.08(\mathrm{~d}, J=$ $8.7 \mathrm{~Hz}), 131.22(\mathrm{~d}, J=97.7 \mathrm{~Hz}), 131.91(\mathrm{~d}, J=3.2 \mathrm{~Hz}) 131.94$ $(\mathrm{d}, J=3.2 \mathrm{~Hz}), 133.40$ (d, $J=100.9 \mathrm{~Hz}) ;{ }^{31} \mathrm{P}$ NMR $(162 \mathrm{MHz}$, $\mathrm{CDCl}_{3}$ ) $\delta 37.62$; anal. calcd for $\mathrm{C}_{23} \mathrm{H}_{29} \mathrm{O}_{2} \mathrm{P}: \mathrm{C}, 74.98 ; \mathrm{H}, 7.93$; found: C, 74.67; H, 8.07.

\section{$(1 R, 2 R, 3 R, 4 R, 5 R)-3-(($ Diphenylphos- phanyl)methyl)isoverbanol (23)}

Phosphine oxide 22 (0.221 g, $0.6 \mathrm{mmol}$ ) was dissolved in dry toluene $(2 \mathrm{~mL})$ in a Schlenk flask under nitrogen. Then, poly(methylhydrosiloxane) (PMHS, $0.3 \mathrm{~mL}$ ) and titanium(IV) isopropoxide $(0.672 \mathrm{~g}, 0.7 \mathrm{~mL}, 2.4 \mathrm{mmol})$ were added dropwise to the solution. The reaction mixture was stirred for $24 \mathrm{~h}$ at $100{ }^{\circ} \mathrm{C}$, cooled, and poured into a solution of $48 \%$ hydrofluoric acid $(3.6 \mathrm{~mL})$ and water $(3 \mathrm{~mL})$. The mixture was stirred overnight and the layers were separated. The aqueous layer was extracted with toluene $(2 \times 10 \mathrm{~mL})$. The combined organic layers were washed with $5 \%$ sodium bicarbonate $(5 \mathrm{~mL})$ and brine $(5 \mathrm{~mL})$. After drying the solution with anhydrous magnesium sulfate and filtration, the solvent was evaporated and the product was purified by flash chromatography on silica gel (hexane/ethyl acetate 80:20). Phosphine 23 (0.131 g, 62\%) was obtained as a colorless oil. ${ }^{1} \mathrm{H} \mathrm{NMR}\left(700 \mathrm{MHz}, \mathrm{CDCl}_{3}\right) \delta 0.93$ (s, 3H, $\left.\mathrm{CH}_{3}\right), 1.14$ (d, J=7.7 Hz, 3H, $\left.\mathrm{CH}_{3}\right), 1.23$ (s, 3H, $\mathrm{CH}_{3}$ ), $1.38(\mathrm{~d}, J=10.1 \mathrm{~Hz}, 1 \mathrm{H}), 1.92-1.96(\mathrm{~m}, 1 \mathrm{H}), 1.98(\mathrm{~m}, 1 \mathrm{H})$, 2.06-2.12 (m, 2H), 2.28-2.33 (m, 1H), 2.36-2.40 (m, 1H), 2.41-2.47 (m, 1H), $4.03(\mathrm{~d}, J=6.2 \mathrm{~Hz}, 1 \mathrm{H}), 7.33-7.39(\mathrm{~m}, 6 \mathrm{H})$, 7.46-7.51 (m, 4H); $\left.{ }^{13} \mathrm{C} \mathrm{NMR} \mathrm{(176} \mathrm{MHz,} \mathrm{CDCl}_{3}\right) \delta 16.35(\mathrm{~d}$, $J=3.5 \mathrm{~Hz}), 23.02,25.07,27.97,30.17(\mathrm{~d}, J=11.8 \mathrm{~Hz}), 35.34$ $(\mathrm{d}, J=6.9 \mathrm{~Hz}), 39.04(\mathrm{~d}, J=11.1 \mathrm{~Hz}), 39.80,48.09,48.88$, $77.23,128.49(\mathrm{~d}, J=6.9 \mathrm{~Hz}), 128.50(\mathrm{~d}, J=6.9 \mathrm{~Hz}), 128.70$, $128.75,128.88(\mathrm{~d}, J=11.8 \mathrm{~Hz}), 132.73(\mathrm{~d}, J=18.0 \mathrm{~Hz}), 132.81$ $(\mathrm{d}, J=18.0 \mathrm{~Hz}), 138.14(\mathrm{~d}, J=9.0 \mathrm{~Hz}) ;{ }^{31} \mathrm{P} \mathrm{NMR}(283.5 \mathrm{MHz}$, $\mathrm{CDCl}_{3}$ ) $\delta$-18.78; anal. calcd for $\mathrm{C}_{23} \mathrm{H}_{29} \mathrm{OP}$ : C, 78.38; H, 8.29; found: $\mathrm{C}, 78.55 ; \mathrm{H}, 8.34$.

\section{Diphenyl $(((1 R, 2 S, 5 R)$ - $\delta$-pinen-4- yl)methyl)phosphine oxide (26)}

Unsaturated phosphine oxide $\mathbf{2 6}$ was obtained applying the procedure described for 21. Allylic alcohol 11 (0.333 g, 2 mmol), DMAP (0.280 g, 2,3 mmol), diphenylphosphine chloride $(0.441 \mathrm{~g}, 2 \mathrm{mmol})$, and toluene $(5 \mathrm{~mL})$ were used for the reaction. The crude product was purified on silica gel (eluent: dichloromethane/diethyl ether 10:90) to give $26(0.547 \mathrm{~g}, 78 \%)$, mp 62-66 ${ }^{\circ} \mathrm{C},[\alpha]_{\mathrm{D}}^{23}-14\left(\right.$ c 2.0, $\left.\mathrm{CHCl}_{3}\right) ;{ }^{1} \mathrm{H}$ NMR $(700 \mathrm{MHz}$, $\left.\mathrm{CDCl}_{3}\right) \delta 0.71\left(\mathrm{~s}, 3 \mathrm{H}, \mathrm{CH}_{3}\right), 0.78\left(\mathrm{~d}, J=7.1 \mathrm{~Hz}, 3 \mathrm{H}, \mathrm{CH}_{3}\right), 0.87$ 
$(\mathrm{d}, J=9.0 \mathrm{~Hz}, 1 \mathrm{H}), 1.18\left(\mathrm{~s}, 3 \mathrm{H}, \mathrm{CH}_{3}\right), 1.71(\mathrm{~m}, 1 \mathrm{H}), 2.06(\mathrm{dt}$, $J=9.0 \mathrm{~Hz}, 5.6 \mathrm{~Hz}, 1 \mathrm{H}), 2.20(\mathrm{td}, J=5.5,1.4 \mathrm{~Hz}, 1 \mathrm{H}), 2.30(\mathrm{~m}$, $1 \mathrm{H}), 3.03-3.13(\mathrm{~m}, 2 \mathrm{H}), 5.16(\mathrm{~m}, 1 \mathrm{H}), 7.42-7.46(\mathrm{~m}, 4 \mathrm{H})$, 7.47-7.51 (m, 2H), 7.72-7.78 (m, 4H); ${ }^{13} \mathrm{C}$ NMR (176 MHz, $\left.\mathrm{CDCl}_{3}\right) \delta 18.22(\mathrm{~d}, J=4.2 \mathrm{~Hz}) 20.59,26.31,27.60(\mathrm{~d}, J=2.1)$, $34.73(\mathrm{~d}, J=2.1 \mathrm{~Hz}), 38.91(\mathrm{~d}, J=68.0 \mathrm{~Hz}), 40.94(\mathrm{~d}, J=$ $1.4 \mathrm{~Hz}), 46.41,47.73(\mathrm{~d}, J=2.8 \mathrm{~Hz}), 128.27$ (d, $J=11.8 \mathrm{~Hz})$, $128.44(\mathrm{~d}, J=11.8 \mathrm{~Hz}), 128.83(\mathrm{~d}, J=11.8 \mathrm{~Hz}), 130.87(\mathrm{~d}, J=$ $9.0 \mathrm{~Hz}), 131.17$ (d, $J=9.0 \mathrm{~Hz}), 131.49(\mathrm{~d}, J=2.8 \mathrm{~Hz}), 131.54$ $(\mathrm{d}, J=2.1 \mathrm{~Hz}), 132.95(\mathrm{~d}, J=97.8 \mathrm{~Hz}), 133.70(\mathrm{~d}, J=$ $96.4 \mathrm{~Hz}), 137.43(\mathrm{~d}, J=10.4 \mathrm{~Hz}) ;{ }^{31} \mathrm{P}$ NMR $(283.5 \mathrm{MHz}$, $\left.\mathrm{CDCl}_{3}\right) \delta 29.93$; anal. calcd for $\mathrm{C}_{23} \mathrm{H}_{27} \mathrm{OP}: \mathrm{C}, 78.83$; H, 7.77; found: C, 78.97; H, 7.51.

\section{(((1R,2R,3S,4S,5S)-3-Hydroxypinan-4- $\mathrm{yl})$ methyl)diphenylphosphine oxide (27)}

Hydroboration-oxidation of $\mathbf{2 6}$ was carried out according to the procedure described for $\mathbf{2 2}$. Unsaturated phosphine oxide $\mathbf{2 6}$ $(0.350 \mathrm{~g}, 1 \mathrm{mmol})$ and BMS $(0.2 \mathrm{~mL}, 10 \mathrm{M}, 2 \mathrm{mmol})$ were used in the hydroboration reaction. meta-Chloroperbenzoic acid $(75 \%, 0.575 \mathrm{~g}, 2.5 \mathrm{mmol})$ was used in the oxidation reaction. The product was purified on silica gel (eluent: dichloromethane/ diethyl ether 50:50) to give $27(0.188 \mathrm{~g}, 51 \%)$. ${ }^{1} \mathrm{H}$ NMR $\left(400 \mathrm{MHz}, \mathrm{CDCl}_{3}\right) \delta 0.99\left(\mathrm{~s}, 3 \mathrm{H}, \mathrm{CH}_{3}\right), 1.04(\mathrm{~d}, J=7.1 \mathrm{~Hz}, 3 \mathrm{H}$, $\left.\mathrm{CH}_{3}\right), 1.12(\mathrm{~d}, J=10.3 \mathrm{~Hz}, 1 \mathrm{H}), 1.21\left(\mathrm{~s}, 3 \mathrm{H}, \mathrm{CH}_{3}\right), 1.72-1.80$ (m, 2H), 2.08-2.20 (m, 2H), $2.31(\mathrm{ddd}, J=15.2,7.5,1.8 \mathrm{~Hz}$, $1 \mathrm{H}), 2.50-2.63(\mathrm{~m}, 2 \mathrm{H}), 4,33(\mathrm{dd}, J=9.8,4.9 \mathrm{~Hz}, 1 \mathrm{H})$, 7.43-7.56 (m, 6H), 7.69-7.79 (m, 4H); ${ }^{13} \mathrm{C}$ NMR (100 MHz, $\left.\mathrm{CDCl}_{3}\right) \delta 14.23,23.27,27.67,29.54,35.36,37.56(\mathrm{~d}, J=$ $69.1 \mathrm{~Hz}), 39.22,48.38(\mathrm{~d}, J=3.2 \mathrm{~Hz}), 49.03,49.76(\mathrm{~d}, J=$ $13.5 \mathrm{~Hz}), 71.47(\mathrm{~d}, J=1.6 \mathrm{~Hz}), 128.71(\mathrm{~d}, J=5.6 \mathrm{~Hz}), 128.82$ $(\mathrm{d}, J=5.6 \mathrm{~Hz}), 130.39(\mathrm{~d}, J=9.5 \mathrm{~Hz}), 131.10(\mathrm{~d}, J=9.5 \mathrm{~Hz})$, $131.61(\mathrm{~d}, J=98.6 \mathrm{~Hz}), 131.82(\mathrm{~d}, J=3.2 \mathrm{~Hz}), 131.88(\mathrm{~d}, J=$ $2.4 \mathrm{~Hz}), 133.61$ (d, $J=100.1 \mathrm{~Hz}) ;{ }^{31} \mathrm{P} \mathrm{NMR}\left(162 \mathrm{MHz}, \mathrm{CDCl}_{3}\right)$ $\delta$ 36.03; anal. calcd for $\mathrm{C}_{23} \mathrm{H}_{29} \mathrm{O}_{2} \mathrm{P}: \mathrm{C}, 74.98 ; \mathrm{H}, 7.93$; found: C, 75.08; H, 7.77.

\section{Supporting Information}

\section{Supporting Information File 1}

General information, experimental procedures and characterization data of the following compounds: $\mathbf{2 , 3}$,

5-8, 10, 11, and 14-18.

[https://www.beilstein-journals.org/bjoc/content/ supplementary/1860-5397-15-242-S1.pdf]

\section{Acknowledgements}

We wish to thank for the financial support received from National Science Centre, grant Preludium 4 No. 2012/07/N/ ST5/02194.

\section{ORCID ${ }^{\circledR}$ iDs}

Anna Kmieciak - https://orcid.org/0000-0003-0002-0338

Marek P. Krzemiński - https://orcid.org/0000-0002-4337-5676

\section{References}

1. Börner, A., Ed. Phosphorus Ligands in Asymmetric Catalysis: Synthesis and Applications; Wiley-VCH: Weinheim, Germany, 2008.

2. Jacobsen, E. N.; Pfaltz, A.; Yamamoto, H., Eds. Comprehensive Asymmetric Catalysis, and Supplements 1 and 2; Springer-Verlag: Berlin, Germany, 2004.

3. Tang, W.; Zhang, X. Chem. Rev. 2003, 103, 3029-3070. doi:10.1021/cr020049i

4. Chen, X.-S.; Hou, C.-J.; Hu, X.-P. Synth. Commun. 2016, 46, 917-941. doi:10.1080/00397911.2016.1171362

5. Hoyt, J. M.; Shevlin, M.; Margulieux, G. W.; Krska, S. W.; Tudge, M. T.; Chirik, P. J. Organometallics 2014, 33, 5781-5790. doi:10.1021/om500329q

6. Padevět, J.; Schrems, M. G.; Scheil, R.; Pfaltz, A. Beilstein J. Org. Chem. 2016, 12, 1185-1195. doi:10.3762/bjoc.12.114

7. Chen, Y.-R.; Duan, W.-L. Org. Lett. 2011, 13, 5824-5826. doi:10.1021/ol2024339

8. Guerrero Rios, I.; Rosas-Hernandez, A.; Martin, E. Molecules 2011, 16, 970-1010. doi:10.3390/molecules16010970

9. Zhong, F.; Luo, J.; Chen, G.-Y.; Dou, X.; Lu, Y. J. Am. Chem. Soc. 2012, 134, 10222-10227. doi:10.1021/ja303115m

10. Wei, Y.; Shi, M. Acc. Chem. Res. 2010, 43, 1005-1018. doi:10.1021/ar900271g

11. Xiao, Y.; Sun, Z.; Guo, H.; Kwon, O. Beilstein J. Org. Chem. 2014, 10, 2089-2121. doi:10.3762/bjoc.10.218

12. Wang, T.; Han, X.; Zhong, F.; Yao, W.; Lu, Y. Acc. Chem. Res. 2016, 49, 1369-1378. doi:10.1021/acs.accounts.6b00163

13. Wauters, I.; Debrouwer, W.; Stevens, C. V. Beilstein J. Org. Chem. 2014, 10, 1064-1096. doi:10.3762/bjoc.10.106

14. Tappe, F. M. J.; Trepohl, V. T.; Oestreich, M. Synthesis 2010, 3037-3062. doi:10.1055/s-0030-1257960

15. Jaklińska, M.; Cordier, M.; Stankevič, M. J. Org. Chem. 2016, 81, 1378-1390. doi:10.1021/acs.joc.5b02337

16. Demay, S.; Volant, F.; Knochel, P. Angew. Chem., Int. Ed. 2001, 40, 1235-1238. doi:10.1002/1521-3773(20010401)40:7<1235::aid-anie1235>3.0.co;2-y

17. Boyd, D. R.; Bell, M.; Dunne, K. S.; Kelly, B.; Stevenson, P. J.; Malone, J. F.; Allen, C. C. R. Org. Biomol. Chem. 2012, 10, 1388-1395. doi:10.1039/c1ob06599h

18. Kmieciak, A.; Krzemiński, M. P. Tetrahedron: Asymmetry 2017, 28 , 467-472. doi:10.1016/j.tetasy.2017.02.003

19. Gavryushin, A.; Polborn, K.; Knochel, P. Tetrahedron: Asymmetry 2004, 15, 2279-2288. doi:10.1016/j.tetasy.2004.05.045

20. Sivik, M. R.; Stanton, K. J.; Paquette, L. A. Org. Synth. 1995, 72, 57-59. doi:10.15227/orgsyn.072.0057

21. Regan, A. F. Tetrahedron 1969, 25, 3801-3805. doi:10.1016/s0040-4020(01)82913-6

22. Konopelski, J. P.; Sundararaman, P.; Barth, G.; Djerassi, C. J. Am. Chem. Soc. 1980, 102, 2737-2745. doi:10.1021/ja00528a036

23. Malkov, A. V.; Pernazza, D.; Bell, M.; Bella, M.; Massa, A.; Teplý, F.; Meghani, P.; Kočovský, P. J. Org. Chem. 2003, 68, 4727-4742. doi:10.1021/jo034179i

24. Gemal, A. L.; Luche, J. L. J. Am. Chem. Soc. 1981, 103, 5454-5459. doi:10.1021/ja00408a029 
25. Brown, H. C.; Singaram, B. J. Org. Chem. 1984, 49, 945-947. doi:10.1021/jo00179a041

26. Brown, H. C.; Garg, C. P.; Liu, K.-T. J. Org. Chem. 1971, 36, 387-390. doi:10.1021/jo00802a005

27. Binder, C. M.; Bautista, A.; Zaidlewicz, M.; Krzemiński, M. P.; Oliver, A.; Singaram, B. J. Org. Chem. 2009, 74, 2337-2343. doi:10.1021/j0802371z

28. Kawashima, H.; Kaneko, Y.; Sakai, M.; Kobayashi, Y. Chem. - Eur. J. 2014, 20, 272-278. doi:10.1002/chem.201303538

29. Reich, H. J.; Wollowitz, S. Org. React. 1993, 44, 1-296. doi:10.1002/0471264180.or044.01

30. Dodge, J. A.; Nissen, J. S.; Presnell, M. Org. Synth. 1996, 73, 110-113. doi:10.15227/orgsyn.073.0110

\section{License and Terms}

This is an Open Access article under the terms of the Creative Commons Attribution License

(http://creativecommons.org/licenses/by/4.0). Please note that the reuse, redistribution and reproduction in particular requires that the authors and source are credited.

The license is subject to the Beilstein Journal of Organic Chemistry terms and conditions:

(https://www.beilstein-journals.org/bjoc)

The definitive version of this article is the electronic one which can be found at: doi:10.3762/bjoc. 15.242 